\title{
VIDNEPSYKOLOGIENS UDVIKLING I FORSKELLIGE DELE AF VERDEN
}

\section{INDTRYK FRA ET VIDNEPSYKOLOGISK SEMINAR}

Af Eva Smith

I dagene 16-19 september 1981 afholdtes en international konference vedrørende vidnepsykologi arrangeret af Det vidnepsykologiske Forskningslaboratorium ved Stockholms Universitet. Gennem en række foredrag, paneldiskussioner og mere uformelle samtaler oprulledes et billede af vidnepsykologiens udvikling og nuværende stade $\mathrm{i}$ forskellige dele af verden. Det fremgik klart, at funktionen og arbejdsområdet er meget forskelligt fra land til land, og at disse forskelle navnlig skyldes tre forhold:

For det forste har det processuelle system i det enkelte land afgørende betydning for vidnepsykologiens arbejdsbetingelser og anvendelsesområde.

For det andet er vidnepsykologiens objekt af stor betydning. Det er væsentligt, om forskeren koncentrerer sig om det bevidst usandfærdige vidne eller om genstanden for hans forskning er det ubevidst usandfærdige vidne.

Endelig er metodevalget af afgørende betydning, idet én retning indenfor vidnepsykologien beskæftiger sig med konkrete vidneudsagn og søger at vurdere disses troværdighed, mens en anden retning søger at finde lovmæssigheder for vidneudsagn $\mathrm{i}$ almindelighed.

Disse tre forhold er til en vis grad uafhængige af hinanden, hvilket bl. a. ses af, at der i USA findes to former for vidnepsykologi, der såvel med hensyn til objekt som metode adskiller sig radikalt fra hinanden. Ikke desto mindre er det klart, at det processuelle system i det enkelte land vil have en betydelig indflydelse på vidnepsykologiens arbejdsområde og dermed på den forskning, der udføres. Dette forhold illustreres måske klarest ved en sammenligning mellem udviklingen i lande med en angelsaksisk retstradition og lande med det, man kunne kalde en germansk retstradition.

\section{Angelsaksisk og germansk retstradition}

Under alle processuelle ordninger er det almindeligt, at retten søger oplysning hos fagmænd, såfremt man står overfor faglige problemer, hvis rækkevidde man ikke umiddelbart har forudsætninger for at overskue. Dette be- 
nævnes i den juridiske terminologi sagkyndige erklæringer (ekspert witness statements). Den måde, på hvilken disse sagkyndige erklæringer præsenteres for retten, er imidlertid i høj grad afhængig af det processuelle system.

I angelsaksisk ret er partsprincippet konsekvent gennemført såvel inden for civilretten som inden for strafferetten. I en straffesag påhviler det således forsvaret - og ikke anklagemyndigheden eller retten - at fremføre de forhold, der taler til gunst for anklagede. Det er derfor ikke almindeligt, som man kender det inden for den germanske retstradition, at retten eller anklagemyndigheden indhenter objektive eksperterklæringer. Sådanne eksperter indkaldes i engelsk ret af parterne - og det ses ikke sjældent, at forsvarer og anklagemyndighed stiller med eksperter, der afgiver meget afvigende udsagn.

Tiltaltes retssikkerhed anses bedst beskyttet gennem et omfattende sæt regler, der skal sikre en "fair trial«. Således må eventuelle tidligere domfældelser for lignende forhold ikke nævnes. Hensynet til tiltaltes retssikkerhed fører således i angelsaksisk ret til, at retten bevidst holdes i uvidenhed om forhold, der må antages at kunne have betydning for vurderingen af skyldspørgsmålet.

Heroverfor står den germanske retspleje, der hviler på den opfattelse, at retten vil kunne afsige den rigtigste dom, såfremt den er $\mathrm{i}$ besiddelse af det størst mulige antal oplysninger, hvad enten disse må anses for at være positive eller negative for den anklagede. I Tyskland har dommeren derfor en aktiv rolle ved fremskaffelsen af sådanne oplysninger.

Skandinavisk retspleje er klart påvirket af dette synspunkt. Mens man stort set har gennemført partsprincippet i civilretten, afsvækkes dette princip i strafferetsplejen, hvor man har gennemført det såkaldte objektivitetsprincip, d.v.s. at anklagemyndigheden $\mathrm{i}$ en straffesag er forpligtet til at opspore og fremlægge alt relevant materiale, hvad enten det må anses for at tale til gunst eller til skade for tiltalte. Baggrunden for denne regel er hensynet til tiltaltes retssikkerhed, som - modsat den angelsaksiske opfattelse - ikke anses for tilstrækkeligt tilgodeset ved partsprincippet.

Under et sådant system er det naturligt, at anklagemyndigheden - under tiden på foranledning af dommer eller forsvarer - retter henvendelse til eksperter eller ekspertorganer, der påtager sig at give retten objektiv oplysning på det pågældende område.

Når vidnepsykologen optræder som ekspert for domstolen bliver hans rolle således en anden inden for angelsaksisk ret end inden for de retssystemer, der er påvirket af germansk ret. 
Denne rolle får indflydelse på hans forskning, hvilket vil blive illustreret i det følgende, hvor der vil blive foretaget en sammenligning mellem vidnepsykologiens udvikling og arbejdsformer inden for et system der er påvirket af angelsaksisk ret (USA) og systemer, der er påvirket af germansk ret (Vesttyskland og Sverige). Når disse tre lande er valgt, skyldes det, at de hver på deres område indtager en særstilling inden for vidnepsykologisk forskning eller praksis.

\section{Vidnepsykologien $i$ angelsaksisk ret}

Som ovenfor nævnt afstikker det processuelle system grænserne for vidnepsykologernes arbejde, men inden for disse grænser har der i USA udviklet sig to retninger, der er forskellige både forsåvidt angår deres objekt som deres arbejdsmetoder.

\section{a) Empirisk arbejdende vidnepsykologer}

Én gruppe amerikanske vidnepsykologer arbejder empirisk og eksperimentelt. De kan være tilknyttet universiteter eller arbejde for offentlige eller private institutioner, og deres arbejde består i forsøg over den menneskelige iagttagelsesevne og hukommelse, og de faktorer, der påvirker denne (f. eks. spørgsmålsformuleringen). Objektet for deres forskning er »the honest, but mistaken witness«, altså ikke det bevidst uærlige vidne. De udfører således deres arbejde uden for retssalen og i princippet uden tilknytning til konkrete sager. De har normalt ikke lejlighed til kontakt med vidnerne, men uddrager på grundlag af deres forskning lovmæssigheder om menneskers iagttagelsesevne, som antages at kunne overføres på det enkelte vidne. Deres inddragelse i processen sker ved, at den ene part - normalt forsvareren indkalder dem med det formål at svække troværdigheden hos den anden parts - normalt anklagemyndighedens - vidner.

Hvis f. eks. forskning viser, at det er meget vanskeligt med sikkerhed at afgøre en bils hastighed, kan sådanne resultater fremlægges som indicium for, at et vidnes gengivelse af denne fart kan være behæftet med fejl, uanset vidnets egen følelse af sikkerhed.

Endvidere arbejder disse vidnepsykologer på at undersøge procedurens betydning for vidneudsagnet. Herhen hører undersøgelser over betydningen af spørgsmålets formulering, d. v. s. undersøgelser over fri forklaring, neutrale spørgsmål, ledende spørgsmål o. s. v. Denne del af vidnepsykologens arbejde er i mindre grad rettet mod ekspertudsagn i konkrete sager, men kan danne basis for lovgivning. 
I de seneste år har man i USA (Loftus 1979) og navnlig i Storbritannien (Bull and Clifford 1978) interesseret sig for identifikationsparader. Begge steder har man i et vist omfang beskæftiget sig med konkrete sager, idet man har benyttet billeder fra den konfrontationsparade, hvor den anklagede blev udpeget. Disse billeder er vist til forsøgspersoner med det formål at påvise skævhed i paraden. Forsøget er ganske enkelt. Man giver vidnernes beskrivelse af gerningsmanden til forsøgspersonerne og spørger, hvem i paraden de ville udpege på grundlag af denne beskrivelse. Hvis et stort antal af forsøgspersonerne udpeger den anklagede, betragtes det som et tegn på, at paraden ikke har været fair.

Resultaterne af denne undersøgelse fremlægges $\mathrm{i}$ retten af forsvareren, eventuelt med afhøring af vidnepsykologen som sagkyndig for forsvaret. I princippet anvendes således den for disse vidnepsykologer almindelige metode: Der sluttes fra nogle forsøgspersoner i et psykologisk eksperiment til et vidne $\mathrm{i}$ en konkret straffesag. Forskellen er, at det psykologiske forsøg cr forctaget på grundlag af straffesagens materiale, mens det normalt foretages på materiale, der er straffesagen uvedkommende.

Et temmeligt stort antal psykologer i USA arbejder empirisk og eksperimentelt med vidneudsagnet. Denne form for forskning har sin rod i de tidligste vidnepsykologiske eksperimenter, der blev udført af tyske og franske jurister og psykologer omkring århundredeskiftet (Trankell 1980). I Tyskland har vidnepsykologen imidlertid en anden rolle $\mathrm{i}$ dag, og den her beskrevne forskning udføres først og fremmest i USA og de øvrige angelsaksiske lande, hvor disciplinen er i rivende udvikling, og der i løbet af de senere år er udkommet adskillige større værker samt et stort antal tidsskriftsartikler.

Metodiske begrcensninger. Der kan dog rettes visse indvendinger mod de empirisk arbejdende psykologers rolle som sagkyndige vidner under konkrete retssager. Det, der er af interesse for retten, er normalt ikke statistiske undersøgelser over den menneskelige iagttagelsesevne, men derimod iagttagelsesevnen hos netop det vidne, der udtaler sig i den konkrete sag med dens særlige omstændigheder.

Normalt vil psykologernes undersøgelser ikke vise absolut korrelation, men blot relativ korrelation. Såfremt man benytter det ovenstående eksempel med vurderingen af bilers hastighed ville absolut korrelation være ensbetydende med, at ingen af forsøgspersonerne var i stand til at gengive hastigheden korrekt, mens relativ korrelation betyder, at de fleste af forsøgspersonerne ikke formåede at give en korrekt vurdering.

Man kan også udtrykke det på den måde, at forsøget viser, at nogle mennesker (om end ganske få) er i stand til at bedømme bilers hastighed. Men 
hvorledes skal retten afgøre, om det pågældende vidne hører til den ene eller den anden gruppe mennesker? Her vil de konkrete omstændigheder få betydning, og disse kan der i følge sagens natur kun i yderst begrænset omfang laves statistiske undersøgelser over. Lad os antage, at vidnet er sportskommentator. Betyder det, at han må antages at tilhøre den lille gruppe mennesker, der er i stand til at bedømme bilers hastighed? Lad os endvidere antage, at der skete en alvorlig ulykke. Vil ophidselsen gøre hans bedømmelse mindre sikker?

Empiriske undersøgelser af den nævnte karakter synes dårligt egnet til at udtrykke noget om det enkelte vidnes evne eller manglende evne. Derimod kan empiriske undersøgelser benyttes, såfremt vidnets udtalelser tillægges en særlig betydning eller en særlig mangel på betydning, fordi han tilhører en bestemt gruppe. En udbredt opfattelse, også blandt dommere (Yarmey 1980), synes at være, at ældre mennesker er særligt pålidelige vidner, og at børn er særligt upålidelige vidner. De senere års undersøgelser tyder på, at den første opfattelse er direkte forkert (Yarmey 1980), og den sidste en sandhed med modifikationer (Marin and Holms 1979).

Størst betydning har disse undersøgelser for lovgivere. Såfremt man ønsker at ændre procedurereglerne, f. eks. vedrørende gennemførelsen af konfrontationsparader eller udspørgningsformen hos politiet eller i retten, er det naturligt at undersøge, hvad empiriske undersøgelser viser om de enkelte metoders indflydelse på sandhedsværdien af en vidneforklaring.

\section{b) Klinisk arbejdende vidnepsykologer}

Der findes imidlertid også en anden retning inden for nordamerikansk vidnepsykologi. Disse vidnepsykologer har samme plads som de øvrige i det processuelle system, idet de normalt optræder for den ene part, i langt de fleste tilfælde for forsvaret. Deres opgave er imidlertid ikke at svække tiltroen til anklagemyndighedens vidner, men derimod at styrke tiltroen til tiltaltes forklaring. Det er de vidnepsykologer, der arbejder med polygraphen.

Polygraphen kendes i Danmark bedre under navnet løgnedetektor. Den er videreudviklet meget i de senere år og måler nu en række forskellige fysiologiske effekter: hjerteslag, puls, svedudsondring osv. Deraf navnet poly... (Raskin 1977, 1979).

Mens de empirisk arbejdende vidnepsykologer fokuserer på den ubevidste usandfærdighed, koncentrerer de klinisk arbejdende vidnepsykologer sig udelukkende om den bevidste usandfærdighed. De arbejder med en bestemt 
person i en konkret sag, og deres opgave er udelukkende at afgøre, om denne person selv tror, at han taler sandhed. Normalt er der tale om, at tiltalte kan styrke sin troværdighed ved at bestå en sådan test (arbejdet udføres således for forsvaret). Det hænder, at anklagemyndigheden opfordrer tiltalte til at rense sig med en løgnedetektortest, men såfremt han nægter at medvirke, må dette efter de angelsaksiske procedureregler ikke nævnes under sagen.

Verdens kendteste forsker på dette specielle område er professor David Raskin fra U.S.A. Han var til stede på kongressen og holdt et meget inspirerende foredrag om de muligheder, der synes at ligge i polygraphen og den grad af perfektionisme, den efterhånden er udviklet til. Det var hans opfattelst, at den sikkerhed med hvilken polygraphen kan skelne (bevidst) usandhed fra sandhed langt overgår det skøn, en psykolog kan udøve (nogle forsøg viser op til $98 \%$ sikkerhed, andre omkring $90 \%$ ).

Nogle deltagere havde imidlertid etiske indvendinger mod polygraphen, andre var betænkelige af en anden grund: mens det skøn, en psykolog anvender vedrørende et vidne eller en tiltalts troværdighed, ikke er væsensforskelligt fra det skøn, dommeren udøver, så er løgnedetektorens skøn principielt unddraget domstolens vurdering.

\section{Vidnepsykologien $i$ germansk ret}

Det, der navnlig adskiller den germanske retstradition fra den angelsaksiske, er som nævnt det forhold, at vidnepsykologen skal søge at hjælpe retten med at finde frem til den objektive sandhed i den enkelte sag. Vidnepsykologen går ind i sagen og udtaler sig som ekspert om det enkelte vidnes troværdighed med henblik på den konkrete sag. Denne ekspertrolle er imidlertid ikke den samme over hele Europa.

\section{a) Vidnepsykologi $i$ Tyskland}

I Tyskland findes en mangeårig tradition for vidnepsykologer som faste sagkyndige tilknyttet domstolene. I en vis forstand kan man sige, at vidnepsykologen her opnår den højeste grad af accept, idet han indgår som en del af det processuelle system. Samtidig må man imidlertid gøre sig klart, at vidnepsykologens arbejdsfelt er yderst begrænset. Hans opgave er at undersøge vidner med det formål at afgive udtalelse til retten om det enkelte vidnes sandfærdighed med henblik på den konkrete sag.

I praksis er det navnlig vidner i sædelighedssager, der undersøges af vidnepsykologer, og et stort antal af disse er børn. Da vidnepsykologerne i langt de fleste tilfælde $(95 \%)$ når frem til, at vidnerne taler sandt (Undeutsch 1981), vil de i praksis normalt komme til at fungere som anklage- 
myndighedens vidner. De tyske vidnepsykologer kan minde om de amerikanske vidnepsykologer, der arbejder med polygraphen. Den tyske vidnepsykolog undersøger ligesom sin amerikanske kollega en bestemt person for at afgøre, hvorvidt dennes udsagn er (bevidst) usandt. Forskellen er, at han ikke benytter en maskine til denne undersøgelse, at han arbejder for retten, ikke for en af parterne, og at han undersøger et vidne, mens polygraphtesten i Nordamerika normalt anvendes på tiltalte.

Metodiske begransninger. Eftersom den tyske vidnepsykolog kun ser og hører den person, hvis troværdighed han skal undersøge, kan han ikke udtale sig generelt om hændelsesforløbet, f. eks. om mulige misforståelser hos vidnet etc. Opgaven er snævert afgrænset til spørgsmålet om, hvorvidt vidnet taler sandhed, eller sagt mere præcist: hvorvidt vidnet selv tror, at det taler sandhed. I konkrete sager er forholdet imidlertid ofte det, at man ikke har grund til at tro, at nogen af parterne bevidst forklarer urigtigt - de forklarer efter alt at dømme om situationen, som de har opfattet den. Problemet er imidlertid, at den anden part har opfattet forholdet helt anderledes, og hans fremstilling - der formentlig er korrekt set fra hans side giver et ganske andet sagsforløb. Ved afvejningen af, hvad der »virkelig" er gået for sig, kan den tyske vidnepsykolog imidlertid ikke være retten til nogen hjælp. Han har ikke mulighed for f. eks. samtaler med gerningsmanden for derigennem at danne sig et mere objektivt billede af, hvad der rent faktisk er foregået.

Ved konferencen deltog såvel tyske vidnepsykologer som jurister. Blandt juristerne kan dommer Bender, der har praktiseret i mere end 30 år nævnes, og blandt psykologerne navnlig professor Udo Undeutsch og professor Arntzen, der begge har mange års praktisk erfaring og en betydelig produktion vedrørende vidnespsykologiske spørgsmål bag sig. Ingen af de tyske deltagere syntes at finde denne indvending væsentlig. Såvel jurister som psykologer mente, at systemet fungerede godt, og at den endelige afvejning af, hvad der var foregået, måtte være dommerens opgave.

\section{b) Vidnespsykologi i Sverige}

I de skandinaviske lande har vidnepsykologien udviklet sig meget forskelligt, uanset at de processuelle systemer ligger tæt op ad hinanden.

Ved Stockholms universitet findes et institut med adskillige medarbejdere, og vidnepsykologer har fået tilladelse til at medvirke i retsprocessen i et omfang, der er ukendt $\mathrm{i}$ andre lande. Arne Trankell og hans medarbejderes arbejde er en del af den germanske tradition, for så vidt som de arbejder med en helt konkret sag, og deres opgave er at give en objektiv vurdering. 
De kan være indkaldt på forsvarerens begæring, men de arbejder i princippet objektivt og for retten.

Derimod er deres opgave ikke - som den tyske vidnepsykologs - begrænset til det snævre område, der består i at afgøre, hvorvidt vidnet (eller tiltalte) selv tror, at han fortæller sandheden. Den svenske vidnepsykolog går ind i sagen som sådan og foretager en helhedsvurdering - af Trankell kaldet »det formella strukturanalysen « (Trankell 1963). Vidnepsykologen taler - uden for rettens formelle atmosfære - med tiltalte, vidner, disses pårørende og andre, der kan bidrage til sagens oplysning. Han foretager i en vis forstand det opklaringsarbejde, som normalt er overladt til politiet. I nogle tilfælde kan man mene, at et dygtigt politiarbejde kunne have afsløret de samme ting, i andre synes det oplagt, at kun en fornyet analyse ud fra en psykologisk synsvinkel har gjort en dybere forståelse af sagens omstændigheder mulig. (F. eks. »Tilfældet Lars«, Trankell, 1965).

Den svenske vidnepsykolog er således som den eneste i verden i stand til at udnytte alle de erfaringer, de forskellige retninger inden for vidnepsykologien har gjort og benytte dem på et konkret tilfælde. Undersøgelsen afsluttes med en vurdering af det mest sandsynlige hændelsesforløb.

\section{c) Vidnepsykologi i Danmark og Norge}

De svenske vidnepsykologers vide beføjelser til endnu engang at gennemgå sagen ville være utænkelige efter det angelsaksiske system, og mange jurister også indenfor germansk orienteret ret vil nok mene, at konklusionen vedrører et område, som kun retten er beføjet til at udtale sig om.

På den anden side er det vanskeligt at se, at det processuelle system, som det ser ud i Danmark og Norge og vist nok også i Tyskland, direkte forbyder en sådan procedure. Også i Sverige er den endelige beslutning naturligvis overladt til domstolene, og i modsætning til mange andre bevismidler, der i dag lægges frem for domstolen, kræver det ingen særlig forkundskab at følge vidnepsykologens tankegang. Vidnepsykologen lægger kendsgerningerne - så vidt de rækker - frem for domstolen, og domstolen afgør herefter, om den kan tilslutte sig vidnepsykologens vurdering af disse kendsgerninger. Denne er ikke principielt forskellig fra f. eks. en lægeerklæring om tiltaltes fysiske eller psykiske tilstand.

I den danske retsplejelov hedder det i $\S 185$ : „Bevisførelse om et vidnes almindelige troværdighed må kun finde sted på den måde og i den udstrækning, som retten bestemmer «.

En nærmere undersøgelse af denne bestemmelse, dens historiske baggrund og ikke mindst dens ikke-absolutte karakter, synes imidlertid at vise, at den forskellige udvikling i Danmark og Sverige næppe alene kan tilskrives denne 
lovbestemmelse. Meget tyder på, at der i et vist omfang har været tale om tilfældigheder samt om personspørgsmål. Større åbenhed hos den juridiske dommer, der første gang fik spørgsmålet om vidnepsykologisk assistance forelagt i Sverige, samt professor Trankells store dygtighed, idet denne metode forudsætter en betydelig tillid fra retsvæsenet til den enkelte psyko$\log$.

I Norge og Danmark er interessen for vidnepsykologi ringe, om end der i Danmark har været foretaget en enkelt empirisk undersøgelse (Kutchinsky, 1969), ligesom der undervises sporadisk i det. Imidlertid har vidnepsykologisk assistance ikke været anvendt $\mathrm{i}$ forbindelse med konkrete retssager.

\section{Vidnepsykologiens fremtid}

Ud over de her nævnte klart vidnepsykologiske problemstillinger blev en række tilstødende områder berørt på konferencen. Det var tydeligt for alle konferencens deltagere, at forskere beskæftiget med vidnepsykologi dækker et meget stort område, og at deres funktion i det enkelte land ikke alene er afhængig af de forskellige retlige systemer, men også af det arbejdsområde vidnepsykologen selv har valgt. Dette er i et vist omfang bestemt af hans uddannelse. Vidnepsykologen vil normalt være psykolog eller jurist, men også psykiatere og sociologer har beskæftiget sig med disciplinen.

Det er måske tvivlsomt, om man i fremtiden kan holde alle disse discipliner under én hat. Umiddelbart synes der at være meget langt mellem den vidnepsykolog, der i sit laboratorium foranstalter forsøg over i hvilket omfang, »the honest, but mistaken witness « er i stand til at opfatte og gengive virkeligheden korrekt, og den forsker, der ved stadig mere forfinede metoder søger at gøre polygraphen i stand til at opfange ethvert fysisk tegn, der kan antyde, at et bestemt menneske ikke fortæller sandheden.

$\mathrm{Da}$ formålet imidlertid er det samme: at forbedre retsprocessen til gavn for retssikkerheden, og begge forskere klart sigter mod den juridiske proces, forekommer det rimeligt at holde dem sammen, uanset at deres arbejde foregår på meget forskellige områder og med meget forskellige metoder. Den almindelige mening på konferencen var, at det havde været umådeligt inspirerende at blive konfronteret med disse forskellige indfaldsvinkler, og der var et betydeligt ønske om at mødes igen inden alt for længe. På den sidste dag blev det vedtaget at stifte en international forening med det formål at fremme psykologiens anvendelse inden for retssystemet. 


\section{LITTERATURLISTE}

Bull, Ray and Brian R. Clifford: The Psychology of Person Identification, Routledge and Paul Kegan, London, Henley and Boston, 1978.

Kutchinsky, Berl: Nogle vidnepsykologiske problemer belyst ved et eksperiment. TfR. 1969, s. 341-368.

Loftus, Flizabeth F.: Eyewitness Testimony, Harvard University Press, Cambridge. Mass. London, England 1979.

Raskin, David and J. A. Podlesny: Physiological Measures and the Detection of Deception. Physiological Bulletin, 1977, 84, 782-799.

Raskin, David: Orienting and Defensive Reflexes in the Detection of Deception. In H. D. Kimmel, E. H. van Olst og J. F. Orlebeke: The Orienting Reflex in Humans. Hillsdale, New Jersey: Erlbaum 1979.

Trankell, Arne: Vittnespsykologins arbetsmetoder. Liber, Stockholm 1963.

Trankell. Arne: Vittnespsykologin som hjälpmedel i svensk rättegång. Liber, Stockholm 1965.

Trankell, Arne: Något om rättsäkerheten vid psykologers sakkunnigbedömning av vittnesbevisningen i svensk brottmålsproces. Svensk Juristtidning 1980, s. $161-173$.

Undeutsch, Udo: Foredrag ved »The Stockholm Symposium on Witness Psycho$\log y 1981$ «.

Yarmey, Daniel: The Psychology of Eyewitness Testimony. The Free Press. New York 1979.

Adresse: Seniorstipendiat, cand. jur. Eva Smith

Eva Smith

Kriminalistisk Institut

Sct. Peders Stræde 19, DK-1453 København K 